\title{
Determinants of thyroid function in neonates at birth
}

\author{
Dr Pikala Tarakeswara Rao ${ }^{1}$, Dr Sai Sunil Kishore ${ }^{2}$, Dr Y V Siva Sankara Murty ${ }^{3}$, Dr Pundarikaksha Varanasi ${ }^{4}$, Dr \\ Madhusudhan $\mathrm{K}^{5}$, Dr Prudhvi Krishna $\mathrm{K}^{6}$ \\ 1,4, 5 Professor, Department of Pediatrics, Maharajah Institute of Medical Sciences, Vizianagaram, ${ }^{2}$ Assistant Professor, \\ Department of Pediatrics, Maharajah Institute of Medical Sciences, Vizianagaram, ${ }^{3}$ Additional Professor, Department of \\ Pediatrics, Maharajah Institute of Medical Sciences, Vizianagaram, ${ }^{6}$ postgraduate, Department of Pediatrics, Maharajah \\ Institute of Medical Sciences, Vizianagaram, India.
}

Address for correspondence: Dr Pikala Tarakeswara Rao, Email: p_tarakeswara@ rediffmail.com

\begin{abstract}
Introduction: Thyroid function test is commonly done in neonatal period to evaluate thyroid status. Interpretation of T4 and Thyroid stimulating hormone (TSH) values in the immediate post natal period is difficult due to wide physiological variation in their levels and potential influence of multiple factors. There is paucity of regarding thyroid function tests and the determinants. Aims: To assess the average level of T4 and TSH and to identify the impact of gestational age, birth weight, gender and mode of delivery on thyroid function in newborn. This is a prospective study conducted in neonatal care unit of tertiary hospital. Total of 108 neonates are enrolled in the study. Studied population were divided into groups based on sex, gestational age, birth weight and mode of delivery. Methods and Material: Venous sample is obtained at the age of 72-120 hours of life from a peripheral vein. The sample is sent for T4 and TSH levels estimation.

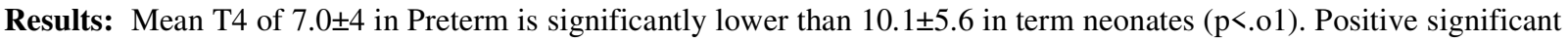
correlation of T4 with gestational age was observed ( $(\mathrm{r}=0.68$ and $\mathrm{P}<0.01)$. TSH negatively correlated significantly with gestational age ( $\mathrm{r}=-0.34$ and $\mathrm{P}<0 \cdot 01)$. Significant difference in mean T4 and TSH was noted in low birth weight (LBW) and in neonates weighing $>2.5 \mathrm{~kg}$. Low birth weight (VLBW) also showed low levels of T4 which was significantly lower compared to low birth weight babies. TSH levels showed no difference between LBW and VLBW neonates. Gender and mode of delivery had no significant impact on T4 and TSH levels. Conclusions: Interpretation of T4 and TSH levels should be done with caution. In the postnatal period normative gestational age and birth weight specific data should be available before interpretation of thyroid levels. This will avoid unnecessary reinvestigations and follow-up.
\end{abstract}

Keywords: TSH, T4 Levels, Postnatal Period, Thyroid Function Tests.

\section{Introduction}

Congenital hypothyroidism reported to occur in India at about 1:2640 which is much higher than the world wide average of 1:3800 [1]. Clinical features are often subtle and many newborn remain undiagnosed at birth. The slow development of recognizable clinical features coupled with the importance of early treatment led to implementation of newborn screening programme worldwide. Unfortunately in our country there is no nationwide screening programme to detect congenital hypothyroidism, despite the fact that the incidence is higher than the world wide average. T4 and TSH are commonly assayed to evaluate thyroid status. T4 and $\mathrm{TSH}$ are dynamic and influenced by many perinatal

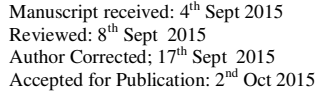

factors making interpretation of results difficult in the immediate postnatal period. Aim of this study is to document level of T4 and TSH in newborn period and to determine the impact of perinatal factors on thyroid status. Implementation of screening programme in our country is constrained due to socio-economic reasons and due to non availability of medical care to majority of newborns.

\section{Subjects and Methods}

This is a prospective study conducted in a neonatal care unit of a tertiary hospital. All neonates with gestational age $>28$ wks and birth weight $>1000$ gms who were admitted during one year period were enrolled in the study. Detailed history and admitting complaints of the 
newborns were recorded. Gestational age was assigned by expanded New Ballard Scoring system. The neonates were weighed with electronic weighing machine with an accuracy of $+/-5 \mathrm{gms}$. Babies with critical illness, complex heart disease, gross malformations, and maternal history of thyroid diseases or intake of antithyroid drugs were excluded from the study. Babies less than 1000 gms or less than 28 wks were excluded from the study. Written informed consent was obtained from parents. Institutional ethical committee approval was also taken before starting the study.

Venous blood sample of $1 \mathrm{ml}$ from the peripheral vein was drawn between 3-5 days of postnatal age for all newborns. $\mathrm{T}_{4}$ and TSH estimated by Enzyme linked inmmunosorbant assay (ELISA) method using antigen coated tube from Monobind USA. Principle of assay is combination of an enzyme immunoassay sandwich method with a final fluorescent detection. The results are automatically calculated by the instrument in relation to calibration curve stored in the memory. For estimation of $\mathrm{T} 4$ and $\mathrm{TSH}$, mean absorbance for each standard, control and sample were determined. The concentrations of each standard against its absorbance were plotted on graph paper.

Categorical outcome variables were analyzed by Chi square test with continuity correction or Fisher's exact test, wherever one or more expected cell size was less than 5. Numerical variables were first tested for normality. Variables whose skewness statistic was more than 1.96 times the standard error of skewness were considered to have skewed distributions; normally distributed variables were compared by Student's t test after evaluating equality of variance by Levene's test. Variables with skewed distribution were compared by Mann Whitney U test. P value of less than 0.05 was taken as significant. Statistical analysis was done by Spss15.0 for windows.

\section{Results}

During the study period, 120 neonates of 3-5 days postnatal age were enrolled in the study. Twelve samples were inadequate/ haemolysed and could not be analysed. Hence data was available for 108 neonates. Table1 shows baseline characteristics of the study population. The mean gestation was $35.7 \pm 3 \mathrm{wks}$ and birth weight was $2358 \pm 690$ gms respectively. There were $60(55.6 \%)$ males and $65(60.2 \%)$ were born by caesarean section. There were $53(49.1 \%)$ preterm neonates, $50(46.3 \%)$ were LBW, 11 (10.2\%) were
VLBW neonates. Twenty five neonates had initial abnormal values during the neonatal period and they were followed up till 8 weeks of postnatal age. The T4 and TSH values were $8.1(6.3,10)$ (median, IQR) and $7.5(4.8,10.7)$ (median, IQR) respectively in the entire study group (Table 2). Table 2 shows comparison of T4 and TSH values according to the gender and route of delivery. T4 and TSH were similar between males and females. T4 values were $9.1 \pm 3.1 \mu \mathrm{g} / \mathrm{dl}$ and $8 \pm 2.5$ $\mu \mathrm{g} / \mathrm{dl}$ among males and females respectively $(\mathrm{p}=0.05)$. TSH values were $8.1 \pm 4.3$ and $7.9 \pm 3.8 \mu \mathrm{IU} / \mathrm{ml}$ among males and females respectively $(\mathrm{p}=0.9)$. T4 and TSH values were similar in neonates born by vaginal route and caesarean section. T4 values were $8.5 \pm 3 \mu \mathrm{g} / \mathrm{dl}$ and $8.2 \pm 2 \mu \mathrm{g} / \mathrm{dl}$ among babies born by caesarian and vaginal route respectively $(\mathrm{p}=0.7)$. TSH values were 8.1 \pm 4 and $7.3 \pm 4 \mu \mathrm{IU} / \mathrm{ml}$ among babies born by caesarian and vaginal route respectively $(\mathrm{p}=0.4)$.

Table 3 shows comparison of T4 and TSH values according to the gestation and birth weight categories. There were 61 neonates weighing $<2.5 \mathrm{~kg}$ and 47 were $>2.5 \mathrm{~kg}$ of birth weight. Relationship between birth weight and mean T4 and TSH values in venous blood at 3 -5day postnatal age showed that babies with low birth weight had low mean $\mathrm{T}_{4}$ values $(7.0 \pm 3.6)$ compared to neonates $>2.5 \mathrm{kgs}(10.8 \pm 5.4)$. Mean TSH levels in low birth weight neonates are higher $(9.0 \pm 8.2)$ compared to neonates weighing $>2.5 \mathrm{kgs}(6.8 \pm 7.4)$. MeanT4 concentration is found to be significantly lower compared to normal weight neonates $(p<0.01)$. Serum TSH concentration is significantly higher compared to neonates weighing $>2.5 \mathrm{kgs}(\mathrm{p}<0.01)$.

Table 3 show comparison of T4 and TSH levels between LBW newborns and VLBW newborns. There is significant difference in meanT4 levels $(p=.004)$. No significant difference is observed in TSH levels. There was significant positive correlation between T4 values and birth weight (Spearman correlation coefficient $=$, $\mathrm{p}<0.01)$. The mean TSH levels showed significant decreasing trend with increase in birth weight (Spearman correlation coefficient $=, \mathrm{p}<0.01$ ).

Mean T4 and TSH values in 54 premature infants were7.0 $\pm 4,9.2 \pm 8$ respectively. The mean T4 and TSH in term neonates were $10.2 \pm 5.6,6.8 \pm 7.2$ respectively. The difference was found to be statistically significant in premature and term neonates. There was progressive increase in mean $\mathrm{T}_{4}$ values with increase in gestational age. (Statistically significant: $\mathrm{r}=+0.63, \mathrm{P}<0.001$ ). High mean TSH levels were seen in premature babies. There 
was progressive decrease in mean TSH values with increasing gestational age which was statistically significant $(\mathrm{r}=-0.39, \mathrm{P}<0.001)$. Among the study group there were $56(\%)$ sick neonates. Premature sick neonates had low T4 levels compared to healthy neonates. Among term neonates no difference in mean T4 and TSH values observed between sick and healthy neonates.
Follow up T4 and TSH values were obtained at 8 wks of age for those who had initial abnormal thyroid function tests. mean T4 and TSH values at 8 wks were 7.465 and 12.185 respectively. Intial T4 and TSH levels were 5.2 and 9.8 respectively. Significant increase was observed in both T4 and TSH in followed up neonates.

Table 1 .Baseline characteristics of study population:

\begin{tabular}{|l|c|}
\hline Characteristic & Number (n=108) \\
\hline Birth weight, gms, m \pm SD & $2358 \pm 692$ \\
\hline Gestation, Wks, m \pm SD & $35.7 \pm 3$ \\
\hline Male (\%) & $60(55.6)$ \\
\hline LBW (\%) & $50(46.3)$ \\
\hline VLBW (\%) & $11(10.2)$ \\
\hline Preterm (\%) & $53(49.1)$ \\
\hline Caesarian delivery (\%) & $65(60.2 \%)$ \\
\hline
\end{tabular}

Table 2: Comparison of thyroid function according to gender and type of delivery

\begin{tabular}{|c|c|c|c|c|c|}
\hline & $\mathbf{n}$ & $\begin{array}{c}\text { T4 } \mu \mathrm{g} / \mathrm{dl} \\
\text { Median (IQR) }\end{array}$ & p value & $\begin{array}{l}\text { TSH } \mu \mathrm{IU} / \mathrm{ml} \\
(\text { Mean } \pm \mathrm{SD})\end{array}$ & p value \\
\hline Total Study sample & 108 & $8.6 \pm 2.9$ & & $8.1 \pm 4$ & \\
\hline $\begin{array}{l}\text { Gender } \\
\text { Male } \\
\text { Female }\end{array}$ & $\begin{array}{l}60 \\
48\end{array}$ & $\begin{array}{c}9.1 \pm 3.1 \\
8 \pm 2.5\end{array}$ & 0.05 & $\begin{array}{l}8.1 \pm 4.3 \\
7.9 \pm 3.8\end{array}$ & 0.9 \\
\hline $\begin{array}{l}\text { Type of Delivery } \\
\text { LSCS } \\
\text { Normal }\end{array}$ & $\begin{array}{l}65 \\
35\end{array}$ & $\begin{array}{l}8.5 \pm 3 \\
8.2 \pm 2\end{array}$ & 0.7 & $\begin{array}{l}8.1 \pm 4 \\
7.3 \pm 4\end{array}$ & 0.4 \\
\hline
\end{tabular}

Table 3: Comparison of thyroid function according to gestation, birth weight and sickness

\begin{tabular}{|l|c|c|c|c|c|}
\hline & $\mathrm{n}$ & $\begin{array}{c}\mathrm{T} 4 \mu \mathrm{g} / \mathrm{dl} \\
(\text { Mean } \pm \mathrm{SD})\end{array}$ & $\mathrm{p}$ value & $\begin{array}{c}\text { TSH } \mu \mathrm{IU} / \mathrm{ml} \\
(\text { Mean } \pm \text { SD) }\end{array}$ & $\mathrm{p}$ value \\
\hline Gestation & 55 & $10.2 \pm 3$ & & $6.8 \pm 4$ & \\
Term & 53 & $7.1 \pm 2$ & & $9.2 \pm 4$ & 0.8 \\
Preterm & & & & $6.8 \pm 4$ & 0.8 \\
\hline Birth Weight & 47 & $10.8 \pm 3$ & $<0.01^{*}$ & $8.9 \pm 4$ & $0.2 \pm 5$ \\
Normal birth weight & 50 & $7.2 \pm 2$ & $0.004^{* *}$ & $10.1 \pm 3.4$ & 0.7 \\
LBW & 11 & $5.8 \pm 1$ & & $9 \pm 4.3$ & \\
VLBW & 52 & $8.7 \pm 1.7$ & 0.03 & & \\
\hline Sickness & 56 & $6.4 \pm 1.5$ & & & \\
Normal Neonates & & & & \\
Sick neonates &
\end{tabular}

(*= comparison of $\mathrm{p}$ value between LBW and normal birth weight neonates

$* *=$ comparison of $\mathrm{p}$ value between VLBW and LBW neonates) 
Figure 1: Scatter plot showing correlation between gestation \& T4

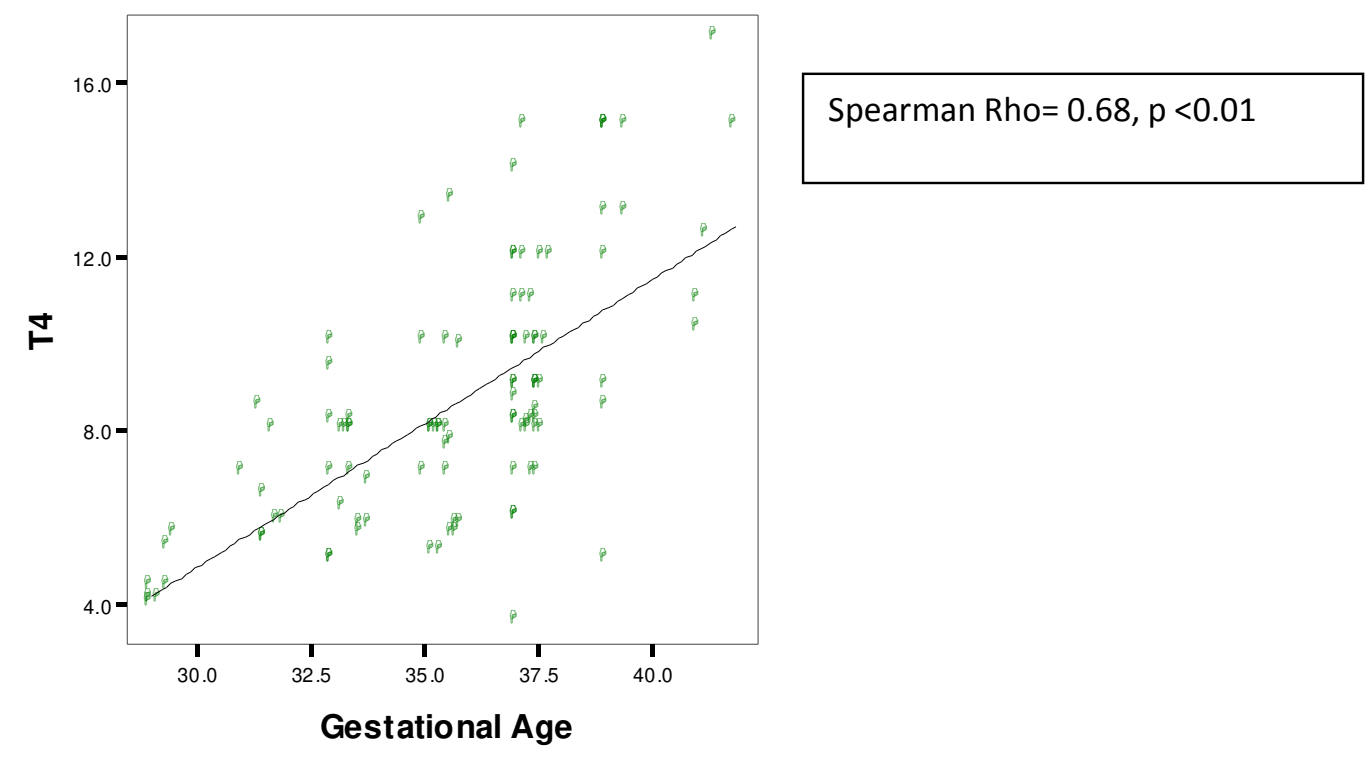

Figure 2: Scatter plot showing correlation between gestation \& TSH

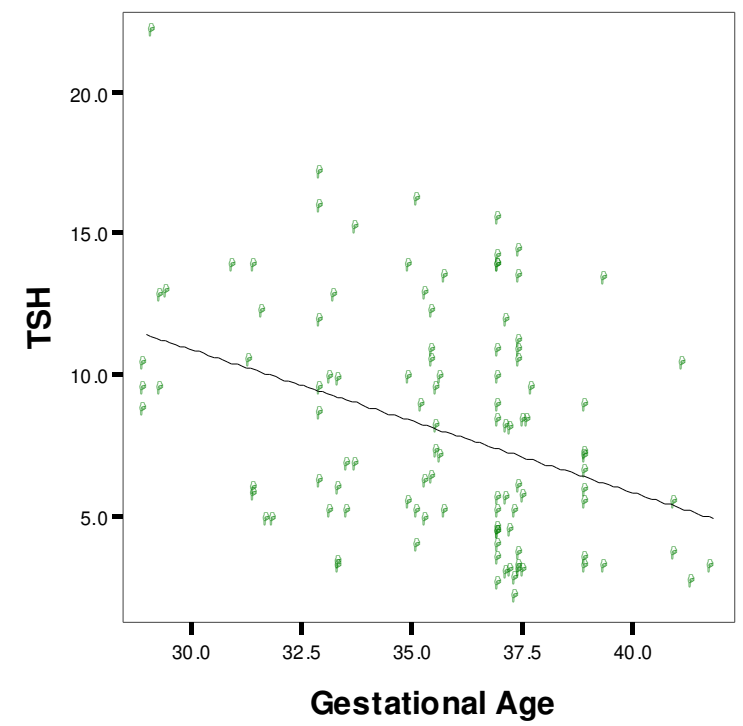

Spearman Rho= $-0.34, p<0.01$ 
Figure 3: Scatter plot showing correlation between birth weight \& thyroid function

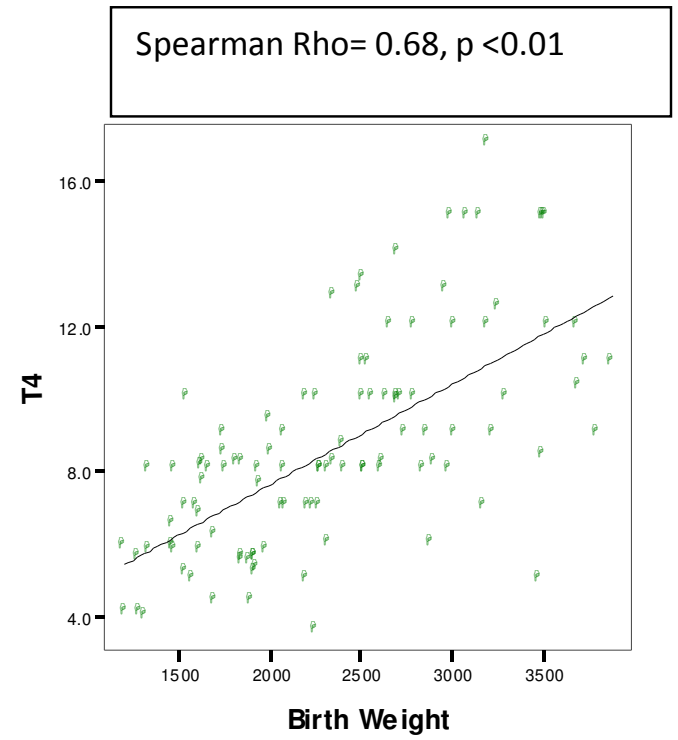

\section{Discussion}

Congenital hypothyroidism is the most common cause of preventable mental retardation. Early diagnosis and treatment will prevent mental retardation. Early diagnosis is hindered by paucity of clinical signs and symptoms. Diagnosis is largely based on biochemical tests. Screening for hypothyroidism is done on cord blood in many countries. No screening programme exits in India for detection of congenital hypothyroidism. Diagnosis is solely done on T4 and TSH level obtained in immediate postnatal period. There is physiological surge of TSH level in immediate post natal period which leads to change in levels of T4 and T3. Levels stabilises during 1-2 days of life [2].

Magnitude of physiological surge is less in preterm neonates. Ideal time for estimating T4 and TSH levels is 3-5 days of life $[3,4]$. In this study samples were drawn between 3 to 5 days of life to avoid physiological influences on the serum levels of T4 and TSH. The study was undertaken to evaluate $\mathrm{T}_{4}$ and TSH values in relation to birth weight, gestational age, sex and mode of delivery.

Reference values of T4 and TSH depend on postnatal age of neonate, gender and method of estimation [5,6]. Out of 108 neonates admitted $55.56 \%$ are males compared to $44.44 \%$ females. No statistically significant difference in levels of $\mathrm{T}_{4}$ and $\mathrm{TSH}$ values is noted in males and females neonates. Chinyanga et al.[7] in their study on 500 term neonates in immediate

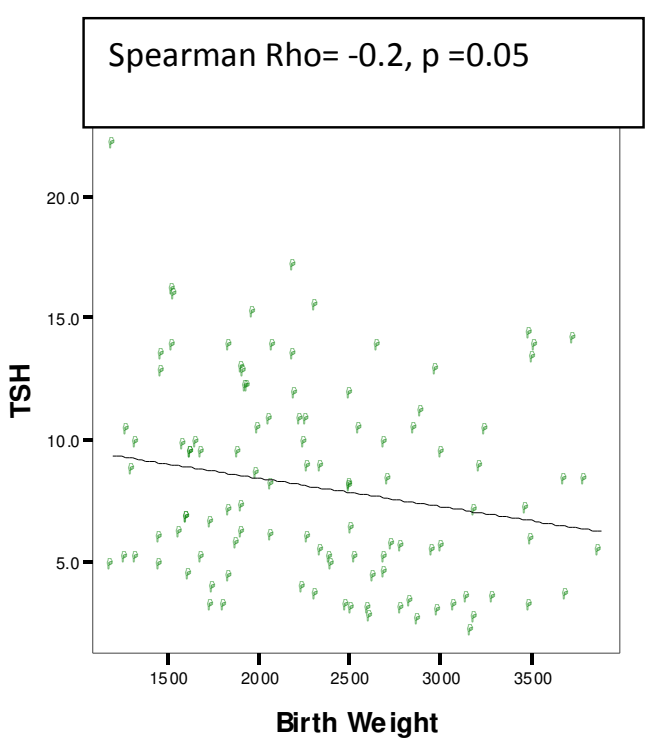

postnatal period found no significant sex related difference in mean $\mathrm{T}_{4}$ and TSH levels. Matlu et al., found no significant gender difference in T4and TSH in neonates from day 1 to 28 day old neonates [8]. Observation of this study is in accordance with previous studies.

Out of 108 newborns admitted only 30 babies delivered normally. The percentage of newborns delivered by ceaserean section enrolled in the study is high. No significant difference in $\mathrm{TSH}$ and $\mathrm{T} 4$ concentration observed in vaginal and ceaserean delivered groups. Eltom A et al., in their study stated that mode of delivery had no significant effect TSH and T4 levels on cord blood samples [9]. Mikelsaar et al., study noted a high TSH levels in caesarean born babies which do not match with the observation of this present study [10].

Most cases were of low birth weight. 61(56.48\%) out of 108 babies were $<2.5 \mathrm{kgs}$ compared to 47(43.52\%) who were $>2.5 \mathrm{~kg}$. Literature review showed conflicting impact of birth weight on T4 and TSH levels. Studies comparing the effect of birth weight on thyroid status were mostly done on cord blood samples. Romagnoli C et al noted no significant influence of birth weight on T4 and TSH[11]. Frank JE et al observed median T4 concentrations for each weight group (in $250 \mathrm{gm}$ increments) increased progressively and significantly up to 2500 gm.[12] Thyrotropin concentration 
correlated inversely with birth weight. Korada M etal[13]., study showed negative correlation of TSH and birth weight. In the present study low mean $\mathrm{T}_{4}$ levels and high TSH levels were observed in low birth neonates. Comparison between LBW and VLBW showed significant difference in $\mathrm{T} 4$ concentration. Significant progressive increasing trend of mean $\mathrm{T}_{4}$ levels with increase in birth weight is observed. Mean TSH levels inversely correlated with birth weight. Magnitude of physiological changes of thyroid hormones in preterm is less compared to term babies. Immaturity of pituitary hypothalamic axis is one reason for altered thyroid status in premature neonates. Moreover critical illness is common in preterm neonates which can further derange thyroid hormones levels[14]. Effect of gestational age on T4 and TSH concentrations were extensively studied. Results are varied because of multiple factors involved in the alteration of serum levels. Desai et al in their study on cord blood observed significant lower mean T4 in preterm neonates compared to term neonates [15].

Levels significantly correlated positively with increase in gestational age. High TSH levels in preterm newborns negatively correlated with gestational age. Low meanT4 and high TSH serum concentration are observed in preterm neonates in our study. T4 levels showed significant positive correlation with gestational age and TSH showed significant negative correlation with gestational age. Observation of this study is in agreement with the findings of Desai et al. Korada M et al also noted negative correlation of TSH concentration with gestational age[13]. Romagnoli et al found no correlation of TSH with gestational age [11]. As several factors can influence the T4 and TSH levels, interpretation of the measured values should be made by keeping these factors in mind. This will help to avoid unnecessary repetition of evaluations, thereby saving on cost as well as the need to subject the newborn to invasive tests. Normative data should be made available to help evaluation and follow up.

\section{Funding: None \\ Conflict of Interest: None \\ Permission from IRB: Yes}

\section{References}

1. Desai MP, Upadhye P, Colaco MP, Mehre M, Naik SP, Vaz FE, et al. Neonatal screening for congenital hypothyroidism using the filter paper thyroxine technique. Indian J Med Res. 1994; 100:36-42.
2. Fisher DA, Odell WD. Acute release of thyrotropin in the newborn. J Clin Invest. 1969 Sep;48(9):1670-7.

3. Raj S, Baburaj S, George J, Abraham B, Singh S. Cord Blood TSH Level Variations in Newborn Experience from A Rural Centre in Southern India. J Clin Diagn Res. 2014 Jul;8(7):PC18-20. doi: 10.7860/JCDR/2014/9058.4603. Epub 2014 Jul 20.

4. Büyükgebiz A. Newborn screening for congenital hypothyroidism. J Pediatr Endocrinol Metab. 2006 Nov;19(11):1291-8.

5. Kapelari K, Kirchlechner C, Högler W, Schweitzer K, Virgolini I, Moncayo R. Pediatric reference intervals for thyroid hormone levels from birth to adulthood: a retrospective study. BMC Endocr Disord. 2008 Nov 27;8:15. doi: 10.1186/1472-6823-8-15.

6.Jain V, Agarwal R, Deorari AK, Paul VK. Congenital hypothyroidism. Indian J Pediatr. 2008 Apr;75(4):3637. doi: 10.1007/s12098-008-0040-7. Epub 2008 May 18.

7. Chinyanga E, Chidede O, Mujaji WB. Thyroid function in neonates from goitre prevalent areas in Zimbabwe. Cent Afr J Med. 1998 May;44(5):127-30.

8.Mutlu M, Karagüzel G, Alıyaziciolu Y, Eyüpolu I, Ok ten A, Aslan Y. Reference interval for thyrotropin and thyroid hormones and ultrasonographic thyroid volume during the neonatal period. J Matern Fetal Neonatal Med. 2012; 25(2):120-124. doi: 10.3109/14767058.2011.561894. Epub 2011 Mar 17.

9. Eltom A, Eltom M, Idris M, Gebre-Medhin M. Thyroid function in the newborn in relation to maternal thyroid status during labour in a mild iodine deficiency endemic area in Sudan. Clin Endocrinol (Oxf). 2001 Oct;55(4):485-90.

10. Mikelsaar RV, Zordania R, Viikmaa M, Kudrjavtseva G. Neonatal screening for congenital hypothyroidism in Estonia. J Med Screen. 1998;5(1):20-1.

11. Romagnoli C, Currò V, Luciano R, Zecca E, De Carolis MP, Tortorolo G, Carta Sorcini M, Tomarchio $\mathrm{S}$, Alessandrini L, Fiore L, et al. [Hypothyroxinemia in the low birth-weight infant in the screening of congenital hypothyroidism]. Pediatr Med Chir. 1982 Nov-Dec;4(6):679-84. 
Research Article

12. Frank JE, Faix JE, Hermos RJ, Mullaney DM, Rojan DA, Mitchell ML, Klein RZ. Thyroid function in very low birth weight infants: effects on neonatal hypothyroidism screening. J Pediatr. 1996 Apr;128(4):548-54.

13. Korada M, Pearce MS, Avis E, Turner S, Cheetham T. TSH levels in relation to gestation, birth weight and sex. Horm Res. 2009;72(2):120-3. doi: 10.1159/000232165. Epub 2009 Aug 18.
14. Pavelka S, Kopecký P, Bendlová B, Stolba P, Vítková I, Vobruba V, Plavka R, Houstek J, Kopecký J. Tissue metabolism and plasma levels of thyroid hormones in critically ill very premature infants. Pediatr Res. 1997 Dec;42(6):812-8.

15. Desai M, Dabholkar C, Colaco MP. Thyroid function in fullterm and preterm newborns. Indian J Pediatr. 1985 Nov-Dec;52(419):599-607.

\section{How to cite this article?}

Pikala Tarakeswara Rao, Sai Sunil Kishore, Y V Siva Sankara Murty, Pundarikaksha Varanasi, Madhusudhan K, Prudhvi Krishna K. Determinants of thyroid function in neonates at birth. Pediatr Rev: Int J Pediatr Res 2015;2(3):30-36. doi: 10.17511/ijpr.2015.i03.06 